\title{
PROSPECTS OF INTERNATIONAL LEGAL COOPERATION OF STATES UNDER U.N. AUSPICES IN DEVELOPING A TREATY ON TRANSNATIONAL CORPORATIONS AND OTHER BUSINESS ENTERPRISES WITH RESPECT TO HUMAN RIGHTS
}

\author{
DMITRY IVANOV, \\ MGIMO University (Moscow, Russia) \\ MARIA LEVINA, \\ Ministry of Foreign Affairs of the Russian Federation (Moscow, Russia)
}

https://doi.org/10.21684/2412-2343-2021-8-1-135-161

The present article is a review of the prospective adoption of a legally binding instrument to regulate, in international human rights law, the activities of transnational corporations (TNCS) and other business enterprises presently being developed under U.N. auspices, aiming for legal control of TNCs' business functioning. The necessity for international legal control of their business' functioning with respect to human rights cannot be underestimated as their influence has grown since striving for dominance in world commodity markets and in leading sectors of the global economy. However, quite a number of scholars question the fact that TNCs are not presently recognized as legal personalities rendering the immediate application of international law principles to their business activities all but practically impossible. At the same time, the majority of so called "soft law" principles developed in the U.N. framework in the past fifty years are nothing more than recommendations to TNCs, thus, emphasizing the urgency of developing a legally binding instrument which primarily governs transnational corporations with respect to human rights. Nevertheless, the prospective adoption of a future treaty, currently being developed by the Open-ended Intergovernmental Working Group on Transnational Corporations and other Business Enterprises with Respect to Human Rights, does not look highly promising due to a number of fundamental flaws and inconsistencies analyzed below.

Keywords: transnational corporations; legal personality of TNCs; human rights violations; Guiding Principles on Business and Human Rights Implementing the United Nations "Protect, Respect and Remedy" Framework; Open-ended Intergovernmental Working 
Group on Transnational Corporations and other Business Enterprises with Respect to Human Rights; legally binding instrument to regulate, in international human rights law, the activities of transnational corporations and other business enterprises.

Recommended citation: Dmitry Ivanov \& Maria Levina, Prospects of International Legal Cooperation of States Under U.N. Auspices in Developing a Treaty on Transnational Corporations and Other Business Enterprises with Respect to Human Rights, 8(1) BRICS Law Journal 135-161 (2021).

\section{Table of Contents}

\section{Introduction}

1. The International Legal Framework for TNCs

2. The Urgency and Practical Importance, from the Perspective of International Law, of State Cooperation Under U.N. Auspices in the Development and Adoption of a Legally Binding Instrument to Regulate, in International Human Rights Law, the Activities of Transnational Corporations and Other Business Enterprises

3. Developmental Stages of a Legally Binding Instrument to Regulate, in International Human Rights Law, the Activities of Transnational Corporations and Other Business Enterprises

4. Review of the Second Revised Draft of the Legally Binding Instrument to Regulate, in International Human Rights Law, the Activities of Transnational Corporations and Other Business Enterprises

\subsection{Rights of Victims}

4.2. Prevention of Human Rights Violations

4.3. Ensuring Access to Justice

4.4. Establishing Institutional International Cooperation Mechanisms Conclusion

\section{Introduction}

An adherent of a complex study of modern globalization, U. Beck, singles out transnational corporations as a key feature of the present-day transnational scene.' There is no doubt that TNCs, with their significant concentration of highly efficient research and industrial potential, substantial economic, managerial, technological, labor and intellectual resources, may at present compete with a number of states and even, to a certain extent, subject such a state's economy to their own political or 
business interests. The growing role of TNCs in world economy in the past decades may be shown by the fact that transnational corporations, having controlled over $50 \%$ of the world industrial output and $60 \%$ of international commodity flow since the $1950 \mathrm{~s}^{2}$, are deemed to be the main operators of the intensifying process of economic globalization. Though in the situation of the COVID-19 pandemic, pursuant to the latest UNCTAD data, 5000 leading TNCs predict a decrease in their profit estimates by up to $30 \%$ for $2020,{ }^{3}$ transnational corporations remain among the most important world economy actors directly affecting both the international markets and the several states' economies.

\section{The International Legal Framework for TNCs}

It should be mentioned that both the definition of a "transnational corporation" and its international legal status has been the subject of discussion in the jurisprudence of international law for quite a number of years. This is not only the result of a wide variety of approaches to interpretating their legal nature but also the absence of a uniform definition of the concept of a TNC in international law. Modern international law science entertains two principal approaches to the issue of a TNC's international personality. The majority of scholars, including I. Brownlie, ${ }^{4}$ A. Cassese ${ }^{5}$ and $\mathrm{M}$. Shaw, ${ }^{6}$ deny the TNCs a right to international personality, since "personality in international law necessitates the consideration of the interrelationship between rights and duties afforded under the international system and capacity to enforce claims."7 Russian scholar I. Lukashuk viewed awarding a corporation legal personality as basically impractical. ${ }^{8} \mathrm{G}$. Velyaminov treats awarding legal personality to TNCs as a "grave mistake since it opens the way to dissolution of the very concept and nature of international law."

2 Seе Родионова И.А., Шувалова О.В. Мировая промышленность, международное производство и прямые иностранные инвестиции // Фундаментальные исследования. 2017. № 9(12). С. 19881992 [Irina A. Rodionova \& Olga V. Shuvalova, World Industry, International Production and Foreign Direct Investments, 9(12) Fundamental Research 1988 (2014)].

3 U.N. Conference on Trade and Development (UNCTAD), Transnational Corporations: Investment and Development, 2020, vol. 27, no. 1 (Jan. 8, 2021), available at https://unctad.org/en/PublicationsLibrary/ diaeia2020d1_en.pdf.

4 See lan Brownlie, Principles of Public International Law ( $2^{\text {nd }}$ ed. 2008).

5 See Antonio Cassese, International Law ( $2^{\text {nd }}$ ed. 2005).

6 See Malcolm Shaw, International Law ( $8^{\text {th }}$ ed. 2017).

7 Id. at 155.

8 Sее Лукашук И.И. Международное право. Общая часть: учебник [Igor I. Lukashuk, International Law. General Part: Textbook] (2005).

9 Seе Вельяминов Г.М. Международное экономическое право и процесс [George M. Velyaminov, International Economic Law and Process] 389 (2004). 
Advocates of the other approach headed by P. Dupuy, ${ }_{1}^{10}$ W. Friedmann, ${ }^{11}$ and K. Ponte ${ }^{12}$ award TNCs with limited (functional) international personality, since in a special situation, in a limited scope and for a particular purpose a TNC may have rights, duties and file international claims under an international treaty or contract.

Under international law the issue of the TNCs' international personality was first raised in the 1960s due to the necessity of solving problems caused by nationalization and permanent sovereignty of newly independent states over their natural resources. The demand for an enhanced control of TNCs' activities followed "the vindication of a 'New International Economic Order' in the early 1970s, which the recently decolonized States pushed forward during that period." ${ }^{\prime 3}$

Thereon, the urgency of international law's control of TNCs was confirmed in the Draft Code of Conduct on Transnational Corporations (hereinafter the draft code of conduct), developed by the ECOSOC subsidiary - the United Nations Commission on Transnational Corporations. Initially, the necessity of such a code was pointed out by the U.N. in 1972, with the issue of the TNCs being raised at the General Assembly XXVII session. ${ }^{14}$ The final stage of negotiations came to an end, but only 18 years later, with the draft Code absorbing the whole variety of ideas and proposals made during the discussions presented on 12 June 1990. ${ }^{15}$

It is worth mentioning that by the time of the draft's completion, the prospect of its adoption was much less favorable than a decade before due to a lack of unity concerning a few of its key provisions and a growing concern among states regarding a decrease in the rate of investment into the developing countries' economies. As a result, in 1992, the chairman of the XLVI session of the General Assembly declared that the Code's adoption remained in favor of a new approach to the issue of foreign investment, thus, as an observer at this body remarked "quietly burying the Code."16

It should be mentioned that the draft Code consolidates the definition of the concept of "transnational corporation" resulting from multiple discussions. In particular, Item 1(a) of the draft Code states that:

10 See Pierre-Marie Dupuy, L'unité de l'ordre juridique international: cours général de droit international public (2002).

11 See Wolfgang Friedmann, General Course in Public International Law (1969).

12 See Karen G. Ponte, Formulating Customary International Law: An Examination of the WHO International Code of Marketing of Breastmilk Substitutes, 5(2) B.C. Int'I \& Comp. L. Rev. 377 (1982).

13 See Olivier De Schutter, Transnational Corporations and Human Rights $2\left(12^{\text {th }}\right.$ ed. 2006).

14 U.N. General Assembly, Special measures in favour of the least developed among the developing: resolution adopted by the General Assembly, A/RES/3036 (XXVII), 19 December 1972 (Jan. 8, 2021), available at https://www.business-humanrights.org/ru/node/178108; https://daccess-ods.un.org/ TMP/1722154.02126312.html.

15 U.N. Economic and Social Council (ECOSOC), Draft Code of Conduct on Transnational Corporations, 12 June 1990, E/1990/94.

16 Sandrine Tesner \& George Kell, The United Nations and Business: A Partnership Recovered 46 (2000). 
1. (a) [The term "transnational corporations" as used in this Code means an enterprise, comprising entities in two or more countries, regardless of the legal form and fields of activity of these entities, which operates under a system of decision-making, permitting coherent policies and a common strategy through one or more decision-making centers, in which the entities are so linked, by ownership or otherwise, that one or more of them may be able to exercise a significant influence over the activities of others, and, in particular, to share knowledge, resources and responsibilities with the others.]

[The term "transnational corporation" as used in this Code means an enterprise whether of public, private or of mixed ownership, comprising entities in two or more countries, regardless of the legal form and fields of activity of these entities, which operates under a system of decision-making, permitting coherent policies and a common strategy through one or more decision-making centers, in which the entities are so linked, by ownership or otherwise, that one or more of them [may be able to] exercise a significant influence over the activities of others, and, in particular, to share knowledge, resources and responsibilities with the others.]

(b) The term "entities" in the Code refers to both parent entities - that is, entities which are the main source of influence over others - and other entities, unless otherwise specified in the Code.

(c) The term "transnational corporation" in the Code refers to the enterprise as a whole or its various entities.

It should be noted that the draft code of conduct has consolidated a broad approach to the concept of transnational corporations including both major corporations enveloping several world regions and smaller companies busy, for example, in a couple of countries. Besides, pursuant to Item 1(c) of the draft code the term "transnational corporation" may be applied both to an enterprise as a whole and to its several divisions. The latter seems reasonable since the law should control not just a TNC as a whole but its single divisions, as well. However, most scholars treat the draft code of conduct with reserve. The majority of critics point out that the Code in fact makes a TNC a subject of public international law through consolidating its rights and obligations towards a state in international law. According to this approach, awarding a TNC with international law personality shall immediately contradict some major international law principles. Thus L. Lialikova points out that:

the role played by TNCs in international relations thanks to their economic power may not entitle them to an international personality or give rise to treating them as recognized international law subjects. While acknowledging the necessity of development of the legal aspect of a TNC functioning, one may not avoid the universally recognized rules and principles of international 
law, primarily the principle of respect of state sovereignty and noninterference into a state's domestic affairs. ${ }^{17}$

A similar TNC definition may be found in the OECD Guidelines for Multinational Enterprises (hereinafter the OECD Guidelines), supplementing the OECD Declaration on International Investment and Multinational Enterprises. These principles were substantially extended in the 2011 revised version, including a new human rights chapter, as well as labor and industrial relationship provisions following the Tripartite Declaration of Principles concerning Multinational Enterprises and Social Policy adopted by the Governing Body of the International Labor Organization. Though Section I(4) of the 2011 update of the OECD Guidelines states that "a precise definition of multinational enterprises is not required for the purposes of the Guidelines, ${ }^{\prime \prime 1}$ that is probably due to a difficulty of finding an interstate consensus on the issue; the authors, however, to avoid doubt, included the provision reading that multinational enterprises usually comprise:

companies or other entities established in more than one country and so linked that they may co-ordinate their operations in various ways. While one or more of these entities may be able to exercise a significant influence over the activities of others, their degree of autonomy within the enterprise may vary widely from one multinational enterprise to another. Ownership may be private, State or mixed ${ }^{19}$.

Having analyzed the Guiding Principles, one cannot help noticing the aforementioned TNC features' similarity to those listed in the draft Code of Conduct on Transnational Corporations.

The next international advisory instrument is the Tripartite Declaration of Principles Concerning Multinational Enterprises and Social Policy adopted in 1977 by the Governing Body of the International Labor Office. Item 6 of this instrument reads that "to serve its purpose this Declaration does not require a precise legal definition of multinational enterprises..$^{20}$ However, the Item continues that multinational enterprises include:

17 ЛяликоваЛ.А. Транснациональные корпорации и проблема определения их национальности // Советский ежегодник международного права. 1982. С. 268-269 [Larisa A. Lialikova, Transnational Corporations and the Problem of Determining Their Nationality, Soviet Yearbook of International Law 256, 268-269 (1982)].

18 Organization for Economic Co-operation and Development, OECD Guidelines for Multinational Enterprises (2011) (Jan. 8, 2021), available at http://dx.doi.org/10.1787/9789264115415-en.

19 Id. at 17.

20 International Labour Organization (ILO), Tripartite Declaration of Principles Concerning Multinational Enterprises and Social Policy, adopted by the Governing Body of the International Labour Office at 
enterprises, whether they are of public, mixed or private ownership, which own or control production, distribution, services or other facilities outside the country in which they are based. The degree of autonomy of entities within multinational enterprises in relation to each other varies widely from one such enterprise to another, depending on the nature of the links between such entities and their fields of activity and having regard to the great diversity in the form of ownership, in the size, in the nature and location of the operations of the enterprises concerned. Unless otherwise specified, the term "multinational enterprise" is used in this Declaration to designate the various entities (parent companies or local entities or both or the organization as a whole) according to the distribution of responsibilities among them, in the expectation that they will cooperate and provide assistance to one another as necessary to facilitate observance of the principles laid down in the Declaration. ${ }^{21}$

Hence this TNC definition, somewhat similar to the aforementioned ones, is also based on a rather loose definition approach.

At the beginning of the $21^{\text {st }}$ century, on 26 August 2003, the United Nations SubCommission on the Promotion and Protection of Human Rights at the $55^{\text {th }}$ session of the Human Rights Commission considered the Draft Norms on the Responsibilities of Transnational Corporations and other Business Enterprises with regard to Human Rights (hereinafter the draft norms). ${ }^{22}$

The distinctive feature of the draft norms on corporation responsibilities was that the responsibility to protect human rights imposed on a TNC did not at the same time relieve the state of the responsibility to secure such norms. Thus, Section A "General Obligations" states that the principal obligation to promote, guarantee implementation, respect and protection of human rights, including by transnational corporations, is with the states, while the instrument's preamble states that:

transnational corporations and other business enterprises, as organs of society, are also responsible for promoting and securing the human rights set forth in the Universal Declaration of Human Rights. ${ }^{23}$

its $204^{\text {th }}$ Session (Geneva, November 1977) and amended at its $279^{\text {th }}$ (November 2000), 295 $5^{\text {th }}$ (March 2006) and $329^{\text {th }}$ (March 2017) Sessions ( $5^{\text {th }}$ ed. 2017) (Jan. 8, 2021), available at https://www.ilo.org/ wcmsp5/groups/public/publication/wcms_094386.pdf.

21 Tripartite Declaration of Principles Concerning Multinational Enterprises and Social Policy, supra note 20 , para. 6 .

22 U.N. Sub-commission on the Promotion and Protection of Human Rights, Draft Norms on the Responsibilities of Transnational Corporations and Other Business Enterprises with regard to Human Rights: draft Norms, submitted by the Working Group on the Working Methods and Activities of Transnational Corporations pursuant to resolution 2002/8, E/CN.4/Sub.2/2003/12, 30 May 2003 (Jan. 8, 2021), available at https://digitallibrary.un.org/record/498842. 
Thus, the draft norms did not aim to modify the scope of a state's responsibility for the promotion and protection of human rights, as provided for by Norm 19 stating that:

Nothing in these Norms shall be construed as diminishing, restricting, or adversely affecting the human rights obligations of States under national and international law, nor shall they be construed as diminishing, restricting, or adversely affecting more protective human rights norms, nor shall they be construed as diminishing, restricting, or adversely affecting other obligations or responsibilities of transnational corporations and other business enterprises in fields other than human rights. ${ }^{24}$

Another distinctive feature of the draft norms is their scope which is not restricted just to states and transnational corporations but also applies to other persons such as, for the purposes of the instrument, contractors, subcontractors, suppliers, or patent holders. In particular, a TNC in its business shall have its contractors or suppliers observe international standards of human rights and freedoms.

It is worth mentioning that, in spite of widespread support for the draft norms from nongovernmental human rights organizations, their further development and adoption prospects gave rise to a vigorous debate resulting in acute confrontation between the business community and the human rights groups. Moreover, this document was not supported by the governments.

As a result, the next step in the effort to establish international law control over transnational corporations and other enterprises in respect to human rights was marked by the Guiding Principles on Business and Human Rights Implementing the United Nations "Protect, Respect and Remedy" Framework" (hereinafter the GPs) considered by the XVII session of the Human Rights Council.

The GPs for a first time consolidate various approaches to a TNC's duty to protect human rights in the course of business - clarifying the rules of corporate conduct that an enterprise is expected to observe. Besides, adoption of the GPs further accelerated the modification of corporate policies, since on their development the companies faced a higher standard of human rights protection in business due to the following factors. Firstly, share index compilers, such as the Dow Jones Sustainability Index or FTSE4Good demand more acute and transparent human rights information. Secondly, most major companies nowadays consider the risk of human rights violation on par with other risks, since the former may imply both a court's costs and reputational or interparty relations damage, as well as diminishing income and public criticism. Thus, risk management has become part of a company's attitude to human rights protection.

24 Draft Norms on the Responsibilities of Transnational Corporations, supra note 22, para. 19.

25 U.N. Human Rights Council, Human rights and transnational corporations and other business enterprises: resolution adopted by Human Rights Council, A/HRC/RES/17/4, 6 July 2011 (Jan. 8, 2021), available at https://digitallibrary.un.org/record/775713? ln=ru. 
However, both the GPs and the preceding advisory instruments share a considerable defect: they neither create new international law obligations for a TNC nor provide an effective remedy for victims of human rights violations.

Thus, within the whole term of the development and adoption of the aforementioned regulations concerning $\mathrm{TNCs}$, the latter still have not been recognized as the subjects of international law since their legal status has not been defined yet in any of the legally binding sources of international law. As a result, nowadays, any direct regulation of transnational corporations' activities may be carried out exclusively pursuant to advisory instruments defining international standards of TNCs'functioning.

\section{The Urgency and Practical Importance, from the Perspective of International Law, of State Cooperation Under U.N. Auspices in the Development and Adoption of a Legally Binding Instrument to Regulate, in International Human Rights Law, the Activities of Transnational Corporations and Other Business Enterprises}

In light of the foregoing, it is important to emphasize that in modern international law, "voluntary codes of behavior need to be given 'teeth' by being made enforceable in the event that they are breached."26 Therefore, the absence of general international law control over TNC business activities heightens the need for a legal mechanism for ensuring TNCs' accountability for human rights violations. While "TNCs aggressively increase their pressure over the world community to initiate such legal rules for capital flow which shall be primarily to their own advantage, ${ }^{127}$ profit-making as a sole priority pursued by TNCs exporting their capital into, above all, developing countries, undermines international requirements for human rights protection: TNCs quite often use child labor, ${ }^{28}$ discriminate against women ${ }^{29}$ or use corrupt

26 Alice De Jonge, Transnational Corporations and International Law: Bringing TNCs Out of the Accountability Vacuum, 7(1) Crit. Perspect. Int'l Bus. 66 (2011).

27 Лабин Д.К. Международно-правовые аспекты регулирования иностранных инвестиций: дис. ... канд. юрид. наук [Dmitry K. Labin, International Legal Aspects of Foreign Investment Regulation: Thesis] 15-16 (1999).

28 According to Amnesty International's report for 2016, quite a few prominent global corporations, including Nestlé, Unilever and Colgate-Palmolive, use palm oil produced by children in dangerous conditions in their products. Preparing its report, Amnesty International followed the links of the aforementioned corporations with the palm oil manufacturer Wilmar, which used hard child labor at Indonesian factories. The report points out that the produce of the aforementioned corporations "is tarnished by outrageous human rights violations, since eight-year-olds work in dangerous conditions." See Amnesty International, The Great Palm Oil Scandal: Labour Abuses Behind Big Brand, ASA21/5184/2016, November 2016 (Jan. 8, 2021), available at https://www.amnesty.org.uk/files/the_great_palm_oil_scandal_Ir.pdf.

29 See, e.g., U.N. Economic and Social Council (ECOSOC), Report of the Commission on Transnational Corporations on the Second Session 1-12 March 1976, 61 ${ }^{\text {st }}$ Session, E/5782; E/C.10/1, Annex 1 "List of Areas of Concern Regarding the Operations and Activities of Transnational Corporations" (Jan. 8, 2021), available at https://www.un.org/ecosoc/en/content/reports-ecosoc-general-assembly. 
practices $^{30}$. That is why the U.N. has initiated work on the development and adoption of a legally binding instrument to regulate, in international human rights law, the activities of transnational corporations and other business enterprises (hereinafter the legally binding instrument).

The importance of proper international legal cooperation under the U.N. has been called forth by the need for a more efficient state supervision and control of TNCs. This, in turn, is caused by the fact that nowadays the duty of protection and promotion of human rights provided for by international law is primarily the duty of a state and may only be applied to a private person, including a transnational corporation, indirectly, through a national legal system. Surely, a state, as the former Head of the U.N. International Court, R. Jennings, and the Institute of International Law member, A. Watts, point out, "may independently choose the manner of performing its international obligations under domestic law."31

It is important to highlight the fact that today multiple legal issues still arise in the course of a state carrying out its duty of supervising the promotion of human rights by a transnational corporation ${ }^{32}$. Among them, there is a legal lacunae in the regulation of TNCs' economic activities: states ignoring human rights violations committed by TNCs in their territory, as well as abetting the latter in such violations.

Besides, one of the most urgent issues is a lack of coordination in domestic policies, especially between the state agencies controlling the TNC's business functioning and the bodies responsible for the state's obligations to protect human rights. Pursuant to the Human Rights Council Resolution 26/22, ${ }^{33}$ coordination should be achieved through, i.a., "developing a national action plan or other such framework.".34 Moreover, according to the Report of the Working Group on the Issue of Human Rights and

30 See, e.g., Филиппов B.P. Франсафрик и этика в международных отношениях // Вестник РудН. Серия: Международные отношения. 2017. № 2. C. 402-415 [Vasily R. Filippov, Françafrique and Ethics in International Relations, 17(2) Vestnik RUDN. International Relations 402 (2017)].

31 Robert Jennings \& Arthur Watts, Oppenheim's International Law 82-83 ( $9^{\text {th }}$ ed. 1996).

32 The most pressing issues in the respective sphere have been thoroughly analyzed in the multiple reports of the Working Group on the Issue of Human Rights and Transnational Corporations and Other Business Enterprises prepared by the U.N. Human Rights Council and the General Assembly, as well as in the reports of the U.N. Secretary General and the High Commissioner for Human Rights. These documents cite the most up-to-date information submitted by the U.N. bodies, specialized agencies, funds or programs: the U.N. Global Treaty of 2000, the World Bank group, the International Finance Corporation, the U.N. Development Program and the International Organization for Migration, as well as by transnational corporations and other business enterprises, national human rights organizations, native peoples' representatives, civil society organizations, and other regional or subregional international organizations.

33 U.N. Human Rights Council, Human rights and transnational corporations and other business enterprises: resolution adopted by the Human Rights Council, A/HRC/RES/26/22, 15 July 2015 (Jan. 8, 2021), available at https://www.refworld.org/docid/5583d84f4.html.

34 Id. at 2. 
Transnational Corporations and other Business Enterprises "National Action Plans on Business and Human Rights" of $2014,{ }^{35}$ it is important that:

any review of the status quo should extend not only to identifying existing policy, laws and regulations but also to assessing the effectiveness of a policy and the practicalities of enforcement within the legal, regulatory and adjudicative frameworks. ${ }^{36}$

National action plans are, as a rule, program strategies worked out by a state to prevent human rights abuse by enterprises, including a description of the state's achievements in the field of human rights promotion, as well as legal omissions to be rectified. It is worth mentioning that in order to assist a state in reaching the aforementioned goal, the Work Group had devised a Guidance on National Action Plans on Business and Human Rights, ${ }^{37}$ introduced at the U.N. Forum on Business and Human Rights taking place on 14-16 November $2016 .{ }^{38}$ Moreover, on the Human Rights Council's adoption of Resolution 26/22 in 2014, four countries had got down to the implementation of a national action plan (September 2013 the United Kingdom of Great Britain and Northern Ireland, December 2013 - the Netherlands, March 2014 - Italy and in April 2014 - Denmark), ${ }^{39}$ by 2019 the number of states having such plans had risen to 22 while in another 23 states the appropriate legal instruments are being developed.

However, despite a number of states developing national plans aimed at increasing efficiency in the implementation of human rights standards and eliminating their

35 U.N. Human Rights Council, Report of the Working Group on the Issue of Human Rights and Transnational Corporations and Other Business Enterprises "National Action Plans on Business and Human Rights," A/69/263, 5 August 2014 (Jan. 8, 2021), available at https://www.un.org/doc/GEN/N14/495/68/.pdf.

Id. at 8 .

37 U.N. Office of the High Commissioner for Human Rights (OHCHR), Guidance on National Action Plans on Business and Human Rights (December 2014) (Jan. 8, 2021), available at https://www.ohchr.org// Business/UNWG20NAPGuidance.pdf.

38 The U.N. Forum is the world's largest annual gathering on business and human rights with more than 2,000 participants from government, business, community groups and civil society, law firms, investor organizations, U.N. bodies, national human rights institutions, trade unions, academia and the media. The U.N. Human Rights Council established the Forum in 2011 to serve as a global platform for stakeholders to "discuss trends and challenges in the implementation of the Guiding Principles and promote dialogue and cooperation on issues linked to business and human rights, including challenges faced in particular sectors, operational environments or in relation to specific rights or groups, as well as identifying good practices." See U.N. Human Rights Council, Human rights and transnational corporations and other business enterprises: resolution adopted by the Human Rights Council, A/HRC/RES/17/4, 6 July 2011 (Jan. 8, 2021), available at https://www.un.org/doc/resolution/gen/G11/144/71/PDF/.pdf.

39 See U.N. Human Rights Council, Report of the Working Group on the Issue of Human Rights and Transnational Corporations and Other Business Enterprises, A/69/263, 5 August 2014 (Jan. 8, 2021), available at https://www.un.org/doc/UNDOC/GEN/N14/495/68/.pdf. 
violation in the course of TNCs' business, quite a few countries still abstain from introducing such legal instruments.

Moreover, there exist the issues of a government being unable to adopt a law which conforms to the international human rights standards, or adopting an inconsistent law, or proving unable to obey such an instrument.

Still, one of the most controversial areas is the protection of working people's rights. Pursuant to the Global Rights Index, devised by the International Trade Union Confederation in 2018:

Shrinking democratic space for working people and unchecked corporate influence are on the rise ... Decent work and democratic rights grew weaker in almost all countries, while inequality continued to grow. ${ }^{40}$

At the same time, though a few governments adopt the respective laws, such legal steps are seldom consistent.

It should also be pointed out that pursuant to the Report of the Working Group on the Issue of Human Rights and Transnational Corporations and other Business Enterprises for 2018, governments neither properly instruct transnational corporations concerning the importance of due care in their protection of human rights, nor properly insist on their reporting on the actual effort to promote human rights in the course of business. ${ }^{41}$

In sum, it should be mentioned that the development of a universal international instrument aimed at TNCs' human rights protection remains urgent for a number of reasons.

Firstly, the international legal initiatives aimed at the control of TNCs' business in view of human rights protection have not just failed to succeed, but, in fact, have shown both a lack of coordination and a lack of a uniform legal position of the states concerning the issue. As a result, modern international law lacks binding rules which govern transnational corporations' adherence to the international legal standards for human rights.

Secondly, the states' classical approach to the matter of legal control of a TNC's business' observance of human rights is based on the presumption of a private party being governed by the domestic law of the state where the transnational corporation carries out its business. Thus, within a particular state international law shall be applicable to an individual or an entity only when in line with- and to the extent of domestic law, including the requirement for observing international legal standards.

40 International Trade Union Confederation, Global Rights Index 2018, at 1 (Jan. 8, 2021), available at https://www.ituc-africa.org/IMG/pdf/ituc-global-rights-index-2018-en-final-2.pdf.

41 U.N. Human Rights Council, Report of the Working Group on the Issue of Human Rights and Transnational Corporations and Other Business Enterprises, A/HRC/38/48, 2 May 2018 (Jan. 8, 2021), available at https://undocs.org/A/HRC/38/48. 
Though nowadays it is the state that bears principal responsibility for a transnational corporation's observance of human rights, it is evident that there are multiple legal problems arising in the course of executing this responsibility, resulting in substantial limitations which inhibit the practice of human implementation in certain world regions. ${ }^{42}$

\section{Developmental Stages of a Legally Binding Instrument to Regulate, in International Human Rights Law, the Activities of Transnational Corporations and Other Business Enterprises}

In the years 2005-2011, the Special Representative of the Secretary General on Human Rights and Transnational Corporations and other Business Enterprises and his work-group carried out research and multiple consultations concerning the issue of business and human rights. This work resulted in the Guiding Principles on Business and Human Rights Implementing the United Nations "Protect, Respect and Remedy" Framework ${ }^{43}$ (hereinafter the GPs) submitted to the $17^{\text {th }}$ session of the Human Rights Council. The most significant shortcoming of the GPs, as we noted earlier, was that they did not create international legal obligations for TNCs. As a result, being approved by the Human Rights Council Resolution 17/4 on 6 July 2011, they were criticized by Ecuador, South Africa and a number of Latin American and African nongovernmental organizations as "a'soft law' instrument, which increasingly is how governments make initial moves into highly complex and conflicted issues." ${ }^{\prime 4}$

Consequently, in 2014 Ecuador initiated adoption at the $26^{\text {th }}$ session of the Human Rights Council of Resolution 26/9, authorizing the establishment of an Open-ended Intergovernmental Working Group on Transnational Corporations and other Business Enterprises with Respect to Human Rights (hereinafter the OEIGWG), mandating the elaboration of an international legally binding instrument on transnational corporations and other business enterprises with respect to human rights (hereinafter the international legally binding instrument). ${ }^{45}$ The preamble to this Resolution shifts the focus of responsibility from transnational corporations to states:

42 Карташкин В.А. Универсализация прав человека и традиционные ценности человечества // Современное право. 2012. № 8. С. 9 [Vladimir A. Kartashkin, Universalization of Human Rights and Traditional Values of Mankind, 8 Modern Law 9 (2012)].

43 U.N. Human Rights Council, Human rights and transnational corporations and other business enterprises: resolution adopted by Human Rights Council, A/HRC/RES/17/4, 6 July 2011 (Jan. 8, 2021), available at https://undocs.org/A/HRC/17/4.

44 John G. Ruggie, Life in the Global Public Domain: Response to Commentaries on the UN Guiding Principles and the Proposed Treaty on Business and Human Rights (January 2015), at 4 (Jan. 8, 2021), available at https://ssrn.com/abstract=2554726.

45 U.N. Human Rights Council, Elaboration of an international legally binding instrument on transnational corporations and other business enterprises with respect to human rights: resolution adopted by Human Rights Council, A/HRC/RES/26/9, 14 June 2014 (Jan. 8, 2021), available at https://undocs.org/ en/A/HRC/RES/26/9. 
the obligations and primary responsibility to promote and protect human rights and fundamental freedoms lie with the State, and [that] States must protect against human rights abuse within their territory and/or jurisdiction by third parties, including transnational corporations.

The first two sessions of the OEIGWG (6-10 July 2015 and 24-28 October 2016) dealt with the analysis of the content, scope, nature and form of the future instrument, while the third session (23-27 October 2017) brought the instrument's development to a new stage, launching an article-by-article discussion of the document. A lot of delegations welcomed the document as being comprehensive, imposing obligations on transnational corporations and other business enterprises and contributing to victims' access to justice stating that:

A legally binding instrument would benefit victims of business-related human rights abuse by ensuring that companies were held accountable and that victims had access to prompt, effective and adequate remedies. Additionally, several delegations considered that such an instrument could be beneficial to business since it would create a level playing field. Uniform rules across jurisdictions would create legal certainty that business would appreciate. ${ }^{46}$

Nevertheless, the Zero draft legally binding instrument to regulate, in international human rights law, the activities of transnational corporations and other business enterprises ${ }^{47}$ (hereinafter the Zero draft) was severely criticized both by private parties and a number of states. In particular, the Russian Federation, European Union and a number of Latin American states (Chile, Colombia, Honduras) submitted formal criticism of a number of this instrument's provisions. ${ }^{48}$ Some states emphasized that discussions on the Zero draft were premature since the Guiding Principles had been unanimously endorsed six years ago, and more time was needed to implement them and that the process risked distracting attention away from such implementation. Apart from this, the treaty did not ensure specific protections for certain vulnerable populations, such as indigenous peoples. Given the disproportionate effect that

${ }^{46}$ U.N. Human Rights Council, Report on the third session of the open-ended intergovernmental working group on transnational corporations and other business enterprises with respect to human rights, A/HRC/37/67, 24 January 2018 (Jan. 8, 2021), available at https://undocs.org/en/A/HRC/37/67.

47 OEIGWG chairmanship, Legally binding instrument to regulate, in international human rights law, the activities of transnational corporations and other business enterprises, Zero Draft, 16 July 2018 (Jan. 8, 2021), available at https://www.ohchr.org/Documents/HRBodies/HRCouncil/WGTransCorp/ Session3/DraftLBI.pdf.

48 U.N. Human Rights Council, Submissions received following the call for comments and proposals on the draft legally binding instrument (Jan. 8, 2021), available at https://www.ohchr.org/EN/HRBodies/ HRC/WGTransCorp/Session4/Pages/Session4.aspx. 
human rights abuses had on women and girls, there was a call for a gendered approach to the treaty.

As for the private sector, the International Organization of Employers, the International Chamber of Commerce, the OECD Advisory Committee on Business and Industry, as well as BusinessEurope on 12 October 2018 submitted a joint response to the Zero draft, emphasizing that:

The Zero Draft Treaty and the Draft Optional Protocol ... do not provide a sound basis for a possible future standard on business and human rights. Both texts incorporate inconsistent provisions that would greatly undermine countries' development opportunities, and they would create a lopsided global governance system that would result in significant gaps in human rights protection. Taken as a whole, the legal regime that the Zero Draft Treaty and Draft Optional Protocol would create is legally imprecise; divergent from established standards and laws; incompatible with the aim of promoting inclusive economic growth and investment; at risk of enabling politicallymotivated prosecutions; and - crucially - not capable of serving all victims of human rights abuses. ${ }^{49}$

After the discussion taking place at the fourth session (15-19 October 2018), it was decided to prepare the revised draft of the legally binding instrument to regulate, in international human rights law, the activities of transnational corporations and other business enterprises (hereinafter the first revised draft), taking into account contributions by the states and the results of informal consultations. Following the fifth session (14-18 October 2019), this draft document was again severely criticized by a number of the OEIGWG member-states. In a year, ahead of the $6^{\text {th }}$ session of the OEIGWG (26-30 October 2020), the Permanent Mission of Ecuador, on behalf of the Chairmanship of the OEIGWG, released a second revised draft of the legally binding instrument to regulate, in international human rights law, the activities of transnational corporations and other business enterprises (hereinafter the second revised draft) ${ }^{50}$ that should serve as the basis for the State-led direct substantive intergovernmental negotiations.

49 The Business and Human Rights Resource Centre, Business response to the Zero Draft Legally Binding Instrument to Regulate, in International Human Rights Law, the Activities of Transnational Corporations and Other Business Enterprises ("Zero Draft Treaty") and the Draft Optional Protocol to the Legally Binding Instrument ("Draft Optional Protocol") (October 2018) (Jan. 8, 2021), available at https://www.business-humanrights.org/ru/node/178108.

OEIGWG chairmanship, Legally binding instrument to regulate, in international human rights law, the activities of transnational corporations and other business enterprises, Second Revised Draft, 6 October 2020 (Jan. 8, 2021), available at https://www.ohchr.org/Documents/HRBodies/HRCouncil/ WGTransCorp/Session6/OEIGWG_ChairRapporteur_second_revised_draft_LBI_on_TNCs_and_OBEs_ with_respect_to_Human_Rights.pdf. 
In our view, a few of the second revised draft provisions still require a major revision, subject to the formerly submitted opinions, criticism and proposals of the states. ${ }^{51}$ It seems reasonable to analyze the prospects of the legally binding instrument's adoption on the strength of a review of those second draft articles, which have been substantially revised in the past five years in comparison to the zero and the first revised drafts, but still may be soundly criticized both by the business community and the OEIGWG member-states.

\section{Review of the Second Revised Draft of the Legally Binding Instrument to Regulate, in International Human Rights Law, the Activities of Transnational Corporations and Other Business Enterprises}

It seems advisable to single out four key aspects of the second revised draft: provisions for the rights and protection of victims (Arts. 4, 5), violations prevention (Art. 6), access to justice (Arts. 7-11) and international cooperation (Arts. 12-15). However, to grasp the legal nature of the prospective treaty, one should primarily review its goals, scope and subject matter.

Though the preamble to the second revised draft emphasizes the duty of a business enterprise to respect all human rights, it is the state that has the primary obligation to respect, protect, fulfill and promote human rights and fundamental freedoms. In its last reading, the preamble has undergone major changes, thus, the list of population groups suffering from especial and disproportional human rights violations due to TNCs' business activities has become non-exhaustive allowing for further extension, such as, for example, the inclusion of internally displaced people. However, the term "vulnerable situation" has grown more obscure given the fact that many different instruments, produced by the ILO or adopted by the U.N. General Assembly, provide guidance on the concept of vulnerability. ${ }^{52}$

However, in spite of some delegations criticizing the preambular paragraph at the fifth session for recalling the nine core international human rights instruments of the U.N. and the eight fundamental Conventions of the ILO, this preambular provision remained unmodified. Such an approach does not seem quite proper since consolidation of the aforementioned instruments may deprive the prospective treaty of flexibility and create problems for the states failing to ratify any of the aforementioned documents.

Moreover, the preambular paragraph contains references to Resolutions of the Human Rights Council and the Commission on Human Rights, some of which are

${ }^{51}$ U.N. Human Rights Council, Report on the fifth session of the open-ended intergovernmental working group on transnational corporations and other business enterprises with respect to human rights, A/HRC/43/55, 9 January 2020 (Jan. 8, 2021), available at https://undocs.org/A/HRC/43/55.

52 See U.N. General Assembly, United Nations Global Plan of Action to Combat Trafficking in Persons, preambular paragraph 3, A/RES/64/293, 12 August 2010 (Jan. 8, 2021), available at https://undocs. org/en/A/RES/64/293. 
procedural in nature and seem neither entirely appropriate for the human rights treaty preamble nor are contained in other human rights treaties.

It is evident that the scope of the second revised draft is more extensive than that of the Zero draft, since the former is legally applicable to "all business enterprises, including, but not limited to, transnational corporations and other business enterprises" (Art. 3(1)). This article of the second revised draft is inconsistent with the Council Resolution 26/9 providing that the OEIGWG's mandate:

shall be to elaborate an international legally binding instrument to regulate, in international human rights law, the activities of transnational corporations and other business enterprises. ${ }^{53}$

It is worth noting that the amendments to Article 3(3) made the provisions governing the scope of the rights to be protected under the international legally binding instrument much less vague. In particular, the expression "all human rights" was changed to:

all internationally recognized human rights and fundamental freedoms emanating from the Universal Declaration of Human Rights, any core international human rights treaty and fundamental ILO convention to which a state is a party, and customary international law. ${ }^{54}$

At the same time the definition of "human rights abuse" in Article 1(2) covering "any harm" to "any person" remains controversial and vague. No less vague seems to be the concept of "environmental rights," also defined in this paragraph, subject to the fact that "the universal human rights treaties do not refer to a specific right to a safe and healthy environment. ${ }^{\prime \prime 5}$

\subsection{Rights of Victims}

Turning to the definition of the term "rights of victims," a key aspect of the second revised draft, one should point out that the very term "victim" provided for by Article 1(1) may give rise to a legal challenge. Thus, the proposed definition lacks determinative features justifying treatment of a person or a group of people as a "victim." At the same time, textual amendments concerning the removal of those

53 U.N. Human Rights Council, Elaboration of an international legally binding instrument on transnational corporations and other business enterprises with respect to human rights: resolution adopted by Human Rights Council, Preamble.

54 OEIGWG chairmanship, Second Revised Draft, Art. 3.

55 See U.N. Human Rights Council, Report of the OHCHR on the Relationship Between Climate Change and Human Rights, A/HRC/10/61, 15 January 2009 (Jan. 8, 2021), available at https://undocs.org/ en/A/HRC/10/61. 
who 'have alleged to have suffered' harm from the definition of "victims" may be noted as positive changes in this article.

Nevertheless, the provisions of the article's updated version also need clarification for categories such as "emotional suffering," "substantial impairment of their human rights" or "harm in intervening to assist victims in distress or to prevent victimization."

It is worth mentioning that the definition of the term "rights of victims" is an almost exact copy of the definition of the term "victim" in Section (A) of the Declaration of Basic Principles of Justice for Victims of Crime and Abuse of Power:

1. "Victims" means persons who, individually or collectively, have suffered harm, including physical or mental injury, emotional suffering, economic loss or substantial impairment of their fundamental rights, through acts or omissions that are in violation of criminal laws operative within Member States, including those laws proscribing criminal abuse of power.

2. A person may be considered a victim, under this Declaration, regardless of whether the perpetrator is identified, apprehended, prosecuted or convicted and regardless of the familial relationship between the perpetrator and the victim. The term "victim" also includes, where appropriate, the immediate family or dependents of the direct victim and persons who have suffered harm in intervening to assist victims in distress or to prevent victimization. ${ }^{56}$

However, the definition of "victim" cited in Article 1 of the second revised draft does not include the reference to domestic law provided for in the aforementioned Declaration ("in violation of criminal laws operative within Member States"). This approach does not seem quite proper since it is often the rules of domestic law that justify treating as "victims" such parties as the immediate family members or dependents of the direct victim.

The vital aspect of the whole international legally binding instrument - the concept of "human rights abuse" provided for in Article 1(2) of the draft - also calls for re-interpretation.

"Human rights abuse" shall mean any harm committed by a business enterprise, through acts or omissions in the context of business activities, against any person or group of persons, that impedes the full enjoyment of internationally recognized human rights and fundamental freedoms, including regarding environmental rights ${ }^{57}$.

56 U.N. General Assembly, Declaration of Basic Principles of Justice for Victims of Crime and Abuse of Power: resolution adopted by the General Assembly, A/RES/40/34, 29 November 1985 (Jan. 8, 2021), available at https://undocs.org/en/A/RES/40/34.

57 OEIGWG chairmanship, Second Revised Draft, Art. 1. 
This definition still seems unjustifiably broad, much broader than the respective provisions of the applicable international human rights instruments. In particular the excessive "blurriness" of the aforementioned provision may be shown by the fact that it may refer to "any harm" and to "any person."The omission of a clear distinction between "human rights abuse" and "violations," provided for in Article 1(2) of the first revised draft, does not seem justified. It seems that a separate definition is to be included for human rights violations in the final text of the international legally binding instrument, since Article 11 "Applicable Law," for instance, includes such a notion as "violations of human rights," not "human rights abuse."

In spite of substantial modification to Article 4 ("Rights of Victims"), it still needs a major revision due to noticeable inconsistencies and deficiencies. Thus, the draft of Article 4 provides for "gender responsive services," a concept unfamiliar to many domestic law systems. The lack of a clear definition of this concept is one of the numerous examples where a varying interpretation of the future international legally binding instrument is possible.

It should be pointed out that the previous reading of the Article did not deal exclusively with the victims' rights (mainly with their access to legal remedies) but with the state responsibilities as well, leading to a visible ambiguity of its title. Nevertheless, the 2020 reading of Article 4 repeats the rights already recognized and secured by international law with their promotion and protection undertaken by the states, thus making such a repetition excessive. For instance, Article 4(c) provides for access to justice and a fair public hearing provided for in multiple international instruments. Thus, the right to a fair, efficient and unhindered access to justice is implied by the Universal Declaration of Human Rights of 1948, the International Covenant on Civil and Political Rights of 1966 and the European Convention for the Protection of Human Rights and Fundamental Freedoms of 1950. Moreover, the existing international legal instruments secure requirements for a fair trial such as a tribunal's authority (Art. 2(2b), Art. 6(2) and Art. 8(3b) of the 1966 Covenant), its independence and impartiality (Art. 14(1) of the 1966 Covenant, Art. 10 of the 1948 Declaration, and Art. 6(1) of the 1950 Convention), a court established by law (Art. 14(1) of the 1966 Covenant) etc. At the same time, the aforementioned subparagraph also provides for "environmental remediation" and "ecological restoration." These measures are of an unclear nature and are not implementable in practice, since "most instruments containing legal obligations for restoration do not contain a clear definition or further clarification on how a State party might restore an ecosystem." ${ }^{\prime 58}$

On the whole, it may be noted that Article 4, along with some other provisions of the second revised draft, in fact launches a special privileged remedy against human rights abuse by a TNC or another enterprise. In particular, such a detailed article may endow victims of transnational corporations' violations with more extensive rights

58 An Cliquet \& Afshin Akhtar-Khavari, Ecological Restoration and International Law 2 (2019). 
than the victims of a state's acts. There is no doubt that such an approach may lead to discrimination of victims through differentiation of abusers. Moreover, it is common knowledge that in numerous international fora the states try to resist attempts to split the system of human rights protection and uphold its integrity, while Article 4 of the international legally binding instrument in fact aims at the opposite. Therefore, it seems reasonable to agree with M. Ajevski:

It seems in international human rights and international criminal law this presumptive unity [normative unity due to their allegiance to the Universal Declaration on Human Rights - added by authors] can not only be shattered from the "outside" - by another regime taken in its broadest sense - but, and probably more dangerously, from the "inside" by one of the sibling institutions. ${ }^{59}$

\subsection{Prevention of Human Rights Violations}

The second component of the revised draft devoted to prevention of human rights violations is not aimed at the outcome of a state's actions. Instead, it addresses the immediate conduct in taking measures of providing minimal standards of aiding enterprises in exercising due care in human rights protection. Though Article 6 provides for a wide variety of prevention measures a state might take to protect human rights, its excessive rigidity deprives the state of freedom to pick the most appropriate means of performing particular duty. It seems advisable to let a state independently select the form and manner of domestic prevention of human rights violations, committed by private parties in accordance with the particulars of its legal system, financial and administrative resources, as well as regional characteristics and legal tradition.

Besides, Article 5(1) fails to clearly define the meaning of "[the states] shall regulate effectively the activities of all business enterprises domiciled within their territory or jurisdiction, including those of a transnational character."This item seems redundant since a state shall anyway control transnational corporations within its territory and jurisdiction.

On the other hand, the reference in Article 6(3)(c) to meaningful consultations with individuals or communities whose human rights "can potentially be affected by the business activities" is not protective enough either, as it diverges, for example, from the accepted norms provided in the ILO Indigenous and Tribal Peoples Convention and the U.N. Declaration on the Rights of Indigenous Peoples. The standard should not be mere consultations but "free, prior and informed consent" as it is stated in Article 10 of the above-mentioned Declaration. ${ }^{60}$ It should not be a stand-alone right but an expression of a broader set of human rights protections

59 See Marjan Ajevski, Fragmentation in International Human Rights Law - Beyond Conflict of Laws, 32(2) Nord. J. Hum. Rights 87, 92 (2014).

60 U.N. General Assembly, United Nations Declaration on the Rights of Indigenous Peoples, A/RES/61/295 (October 2007), Art. 10 (Jan. 8, 2021), available at https://undocs.org/A/RES/61/295. 
that secure the rights of "women, children, persons with disabilities, indigenous peoples, migrants, refugees, internally displaced persons and protected populations under occupation or conflict areas ${ }^{161}$ to control their lives, livelihoods, lands and other rights and freedoms.

\subsection{Ensuring Access to Justice}

The next crucial component of the second revised draft provides for the victims' access to justice. Thus, Article 8, which is devoted to the responsibility of legal entities and individuals, has been substantially modified as compared to the 2018 version. Now, it directly obligates a state to provide for "a comprehensive and adequate system of legal liability" in its domestic law without, however, any reference to the nature of such a system. Moreover, this Article's provisions for the criminal liability of an entity seem especially moot, since there is no criminal liability for an entity not only in Russian Federation law, but also in the law of Eastern European countries such as, Bulgaria, Hungary or Poland.$^{62}$ Thus, on implementation, it shall bar a number of states' accession to the prospective treaty.

At the same time Article 8(7) seems far too broad since it remains unclear to what extent liability would be placed on companies for failing to prevent harm committed by another legal or natural person with whom they have a business relationship. In its present reading Article 8(7):

States Parties shall ensure that their domestic law provides for the liability of legal or natural or legal persons conducting business activities, including those of transnational character, for their failure to prevent another legal or natural person with whom it has a business relationship, from causing or contributing to human rights abuses, when the former legally or factually controls or supervises such person or the relevant activity that caused or contributed to the human rights abuse, or should have foreseen risks of human rights abuses in the conduct of their business activities, including those of transnational character, or in their business relationships, but failed to put adequate measures to prevent the abuse..$^{3}$

may seem to impose a disproportionate responsibility on a company for failure to prevent damage caused by a third party.

Nor are the procedural aspects of access to justice quite clear: Article 7(6), which provides for the reversal of the burden of proof, needs further clarification

61 OEIGWG chairmanship, Second Revised Draft, Art. 6.

62 Seе Наумов A.В. Уголовная ответственность юридических лиц // Lex Russica. 2015. № 7. C. 57-63 [Anatoly V. Naumov, Criminal Liability of Legal Entities, 7 Lex Russica 57 (2015)].

63 OEIGWG chairmanship, Second Revised Draft, Art. 6. 
of the circumstances making such a reversal proper, since in its present version the provision shall be at variance with the basic proper legal procedure principle.

It seems necessary to emphasize that the existing provisions of Article 9 ("Adjudicative Jurisdiction") have been extended by the inclusion of forum necessitatis:

Courts shall have jurisdiction over claims against legal or natural persons not domiciled in the territory of the forum State if no other effective forum guaranteeing a fair trial is available and there is a sufficiently close connection to the State Party concerned. ${ }^{64}$

However, the aforementioned Article aimed at legal control of the issues of the state jurisdiction over human rights violations is silent as to a possible conflict of national jurisdictions over human rights violations, giving rise to exterritorial jurisdiction that may result in violation of the principle of state sovereignty and state equality. Moreover, justification of a court's jurisdiction by "a sufficiently close connection" may cause the risk of "forum shopping" by the victim. For instance, Laurence R. Helfer finds compelling arguments against permitting such a practice:

Permitting more than one review body to entertain the same complaint at the same time is highly inefficient, wasting scarce judicial resources and needlessly duplicating proceedings. These concerns have become even more pressing in recent years as the tribunals' workloads have increased while their resources have remained stagnant. Nor are efficiency losses compensated for by the benefits of increased dialogue over human rights norms that successive petition cases can engender ${ }^{65}$.

Article 10, avoiding the statute of limitations in respect of human rights violations that may be qualified as a crime under international law, fails to define crimes or offences that may be included under"all violations of international law which constitute the most serious crimes of concern to the international community as a whole."Within the theory of international law, a few scholars indeed recognize the TNCs' liability for a number of really serious crimes under international law..$^{66}$ This approach is based on jus cogens - peremptory norms of international common law recognized by the international community as a whole as unavoidable, which may be changed exclusively by another jus cogens norm of the same nature. The U.N. International Law Commission initially referred to jus cogens such provisions as the prohibition of aggressive war,

64 OEIGWG chairmanship, Second Revised Draft, Art. 7(8).

65 Laurence R. Helfer, Forum Shopping for Human Rights, 148(2) U. Pa. L. Rev. 801 (1999).

66 See Jordan J. Paust, Human Rights Responsibilities of Private Corporations, 35(3) Vanderbilt J. Transant'| L. 801 (2002); Steven R. Ratner, Corporations and Human Rights: A Theory of Legal Responsibility, 111(3) Yale L.J. 443 (2001). 
genocide, slave trade and piracy. Thereon, the prohibition of racial discrimination, the principles of permanent sovereignty over natural resources and self-determination were included into the list. ${ }^{67}$ On our part, it seems worth noting that the jus cogens discussion now in progress within the ILC framework deals exclusively with the states. ${ }^{68}$ As a result, it remains unclear not only which human rights violations should be treated as the "most serious crimes rousing concern of the global community" but how a TNC may be held accountable for such an offence.

As to Article 10's (9 and 10) provisions for recognition and enforcement of judgments, one should mention the limited circumstances under which recognition and enforcement may be refused at the request of the defendant. For instance, the second revised draft fails to provide that when the judgment was obtained by fraud, it may cause refusal of recognition and enforcement. In general, to our mind, the aforementioned provisions of Article 10 should be revised, subject to the terms of the Convention on the Recognition and Enforcement of Foreign Judgments in Civil or Commercial Matters of 2 July 2019.

Certain attention should be paid to Article 11(2) Applicable Law providing for:

all matters of substance regarding human rights law relevant to claims before the competent court may, upon the request of the victim of a businessrelated human rights abuse or its representatives, be governed by the law of another State where:

a) the acts or omissions that result in violations of human rights covered under this (Legally Binding Instrument) have occurred; or

b) the natural or legal person alleged to have committed the acts or omissions that result in violations of human rights covered under this (Legally Binding Instrument) is domiciled. ${ }^{69}$

The victim of abuse's right to demand trial on the merits by a common law court of the other Party does not seem quite proper, for instance, in a criminal case. A court shall consider a criminal case and rule pursuant to domestic law where necessary, taking into account the applicable provisions of lex loci delictus. Therefore, it does not seem appropriate from a legal standpoint to allow victims to choose the applicable substantive law.

67 Sее Синякин И.И., Скуратова А.Ю. Нормы јus cogens: исторический аспект и современное значение для международного права // Вестник Пермского университета. Юридические науки. 2018. № 41. C. 526-545 [Ivan I. Sinyakin \& Alexandra lu. Skuratova, Jus Cogens: The Historical Aspect and Contemporary Value for International Law, 41 Perm University Herald. Juridical Sciences 526 (2018)].

International Law Commission, Fourth report on peremptory norms of general international law (jus cogens) by Dire Tladi, Special Rapporteur, Seventy-first session (29 April-7 June and 8 July-9 August 2019), A/CN.4/727 (2019) (Jan. 8, 2021), available at https://documents-dds-ny.un.org/doc/UNDOC/ GEN/N19/024/33/PDF/N1902433.pdf. 


\subsection{Establishing Institutional International Cooperation Mechanisms}

The fourth aspect of the revised draft is focused on international cooperation in establishing institutional mechanisms as a key cooperation feature. Thus, a provision in Article 15 of the second revised draft for a special committee seems excessive as there already exists the U.N. Conference on Trade and Development (UNCTAD), which reviews, inter alia, various aspects of the TNCs'functioning, including human rights. Along with the UNCTAD, the issues of promotion and protection of human rights and freedoms, in regards to TNCs, as well, is dealt with by the special conventional U.N. bodies: the Committee on Economic, Social and Cultural Rights, the Human Rights Committee, the Committee on the Elimination of Racial Discrimination, the Committee on the Elimination of Discrimination against Women, etc. Moreover, the mandate of the proposed special committee may intersect with the authority of the Human Rights Council. As a result, a new body established under the prospective treaty may cause the risk of parallel functioning and split the effort of the international community in this area.

Besides, there is a serious concern as to the proposed Committee's scope of authority. Primarily, such functions as those provided for in Item 4:

make general comments and normative recommendations on the understanding and implementation of the (Legally Binding Instrument) based on the examination of reports and information received from the State Parties and other stakeholders;

consider and provide concluding observations and recommendations on reports submitted by State Parties as it may consider appropriate and forward these to the State Party concerned that may respond with any observations it chooses to the Committee. The Committee may, at its discretion, decide to include these suggestions and general recommendations in the report of the Committee together with comments, if any, from State Parties ... ${ }^{70}$

look like an attempt to interfere with a state's authority to interpret and apply an international treaty. A certain concern may be caused by the possibility of the procedure of the Committee's consideration of a state's report being politicized due to a high level of independence and the proposed mechanism of its composition.

At the same time, the current version of the second revised draft does not endow the Committee with the authority to consider individual complaints which would have furthered the promotion of human rights and freedoms by TNCs. The authority should also afford the Committee the ability to investigate under the international legally binding instrument. In particular, the Committee could have the authority to acquire information and investigate complaints concerning repeated human rights violations by TNC businesses in the member-states. This authority might be optional,

70 OEIGWG chairmanship, Second Revised Draft, Art. 15(4). 
i.e. the state ratifying or acceding the treaty may declare its non-recognition of this authority. At present, this practice is successfully implemented by the Committee against Torture: a body of ten independent experts monitoring the state-parties' adherence to the Convention against Torture and Other Cruel, Inhuman or Degrading Treatment or Punishment.

The issue of the International Fund for Victims to be established under Article 15 may also give rise to dispute. Thus, pursuant to Item 7 :

States Parties shall establish an International Fund for Victims covered under this (Legally Binding Instrument), to provide legal and financial aid to victims. This Fund shall be established at most after $(\mathrm{X})$ years of the entry into force of this (Legally Binding Instrument). The Conference of Parties shall define and establish the relevant provisions for the functioning of the Fund. ${ }^{71}$

The draft fails to clarify both the procedure of the Fund's establishment and the scope of its functioning. Nor is it clear how this Fund should be managed and financed, nor who should be entitled to benefit on its account.

On the whole, it should be noted that though a provision for institutional mechanisms is necessary for the proper implementation of a legally binding instrument, it seems advisable to discuss its content on achievement of a better consensus on the substance of the document. It stands to reason to agree with the formal position of the International Commission of Jurists, stating that:

Rather than entirely replicating the existing system, the new treaty on business and human rights could build on the best elements of that system but move beyond them and establish practices and mechanisms to strengthen the functions and enhance the effectiveness of the international system of treaty monitoring and supervision. ${ }^{72}$

\section{Conclusion}

In conclusion, it should be mentioned that in the framework of an international agenda, the development and adoption of an international legally binding instrument should undoubtedly further the efficiency of prevention and mitigation of the consequences of human rights abuse in the course of business. No less important should be the improvement of a victim's access to effective remedies and strengthening cooperation within the international community concerning the issue.

71 OEIGWG chairmanship, Second Revised Draft, Art. 15(7).

72 International Commission of Jurists, Comments and recommendations on the Revised draft of an International Legally Binding Instrument on Business and Human Rights (February 2020), at 12. 
Having analyzed several articles of the draft, the authors hereof managed to show the substantial modification of the second revised draft as compared to the initial version. The inclusion of provisions concerning human rights activists, indigenous peoples and gender issues may be counted as a positive amendment. Moreover, modification of terminology and certain conceptual definitions evidences a fuller coordination of the revised draft with the documents developed by the Human rights Council and the regional bodies; Sustainable Development Goals; OECD Guidelines for Multinational Enterprises and, mostly, the U.N. Guiding Principles on Business and Human Rights.

Nevertheless, it should be noted that major deficiencies and insufficient elaboration of many of the second revised draft articles substantially undermine the progressive character of its provisions. Thus, some definitions are strikingly vague (e.g. "re-victimization," "the most serious crimes of concern to the international community as a whole"); there is an evident dissonance between its conceptual structure and categories of international law (e.g. "unnecessary delay" or "comprehensive and adequate system of legal liability"); there is a duplication of international agreements already adopted under the U.N. auspices; and, a lack of dispositive norms that could involve state discretion in terms of prevention human rights violations or abuses. All these gaps and shortcomings prevent treating this second revised draft as a sufficiently elaborated instrument; they will also provide the ground for submissions following the call for additional textual suggestions on the revised draft legally binding instrument.

As to the probability of adoption of the international legally binding instrument on transnational corporations and other business enterprises with respect to human rights, it should be mentioned that disagreements on the need to eliminate a number of this draft's provisions (in particular, review of the articles governing the scope of the prospective treaty, the volume and nature of the rights to be controlled, a state's liability and jurisdiction to apply the national institutional mechanisms, etc.) may lead to three possible alternatives: either, like the Draft Code of Conduct of TNCs, it shall never come to life, or in the course of the OEIGWG long-term effort, the draft instrument shall be fundamentally changed, including its aim and scope of application; or "an equivalent to the Migrant Workers Convention, which entered into force in 1990 but has not been ratified by a single migrant worker-receiving country"173 shall be adopted.

There is no doubt that the international legally binding instrument shall make a positive contribution to further development and improvement of the international legal mechanism for the promotion and protection of human rights and freedoms. However, one should concur with the formal opinion of the Russian Federation declared as to the Zero draft in February 2018:

\footnotetext{
73 Ruggie 2015, at 4.
} 
Though quite a few of its provisions are evidently based on good will and the theory of human rights, they are still somewhat far from reality and the context of their proposed implementation. An instrument efficient as guiding principles may not prove viable as an obligation. ${ }^{74}$

\section{References}

Ajevski M. Fragmentation in International Human Rights Law - Beyond Conflict of Laws, 32(2) Nord. J. Hum. Rights 87 (2014). https://doi.org/10.1080/18918131.201 4.897795

De Jonge A. Transnational Corporations and International Law: Bringing TNCs Out of the Accountability Vacuum, 7(1) Crit. Perspect. Int'I Bus. 66 (2011). https://doi. org/10.1108/17422041111103840

Filippov V. Françafrique and Ethics in International Relations, 17(2) Vestnik RUDN. International Relations 402 (2017). https://doi.org/10.22363/2313-0660-2017-172-402-415

Paust J.J. Human Rights Responsibilities of Private Corporations, 35(3) Vanderbilt J. Transant'I L. 801 (2002).

Ponte K.G. Formulating Customary International Law: An Examination of the WHO International Code of Marketing of Breastmilk Substitutes, 5(2) B.C. Int'I \& Comp. L. Rev. 377 (1982).

Ratner S.R. Corporations and Human Rights: A Theory of Legal Responsibility, 111(3) Yale L.J. 443 (2001). https://doi.org/10.2307/797542

Rodionova I. \& Shuvalova O. World Industry, International Production and Foreign Direct Investments, 9(12) Fundamental Research 1988 (2014). https://doi.org/10.17513/ fr.36476

Sinyakin I. \& Skuratova A. Jus Cogens: The Historical Aspect and Contemporary Value for International Law, 41 Perm University Herald. Juridical Sciences 526 (2018). https:// doi.org/10.17072/1995-4190-2018-41-526-545

\section{Information about the authors}

Dmitry Ivanov (Moscow, Russia) - Associate Professor, Department of International Law, MGIMO University (76 Vernadskogo Av., Moscow, 119454, Russia; e-mail: prof.ivanovdv@gmail.com).

Maria Levina (Moscow, Russia) - Secretary-Referent, First CIS Department (1CISD), Ministry of Foreign Affairs of the Russian Federation (32/34 Smolenskaia-Sennaia Sq., Moscow, 119200, Russia; e-mail: marylevis95@mail.ru).

74 Comments and proposals of the Russian Federation on the draft legally binding instrument on transnational corporations and other business enterprises with respect to human rights No. LW/NS, 27 February 2018. 